\title{
Latent Infection of Potato Seed Tubers by Phytophthora infestans During Long-Term Cold Storage
}

\author{
Dennis A. Johnson and Thomas F. Cummings, Department of Plant Pathology, Washington State University, Pull-
} man 99164-6430

\begin{abstract}
Johnson, D. A., and Cummings, T. F. 2009. Latent infection of potato seed tubers by Phytophthora infestans during long-term cold storage. Plant Dis. 93:940-946.

Latent infection of potato seed tubers by Phytophthora infestans was determined following inoculation of tubers and typical seed tuber storage conditions in the Pacific Northwest. Severity of late blight increased over 182 to 209 days during two storage seasons at mean temperatures of 4.1 and $4.2^{\circ} \mathrm{C}$. From 0 to $44 \%$ of inoculated tubers sampled at given intervals were asymptomatic. However, P. infestans sporangia were observed on slices from these tubers when incubated in a humidity chamber at $15^{\circ} \mathrm{C}$ or late blight symptoms developed in asymptomatic tubers obtained following storage when incubated at 22 to $23^{\circ} \mathrm{C}$ for 3 weeks. Development of $P$. infestans sporangia and symptoms of late blight in asymptomatic seed tubers indicated latent infection of tubers by $P$. infestans during long-term cold storage. Sporulation was observed after 21 to $24 \mathrm{~h}$ on symptomatic tubers and 6 to 20 days on asymptomatic tubers that were removed from storage and incubated in a humidity chamber at $15^{\circ} \mathrm{C}$. Latent infection of seed tubers and production of viable sporangia of $P$. infestans were demonstrated after long-term cold storage of infected potato tubers.
\end{abstract}

Persistence of Phytophthora infestans (Mont.) de Bary, the cause of late blight of potato (Solanum tuberosum subsp. tuberosum L.), from year to year is a critical component of late blight epidemics. Understanding the means of pathogen survival is a major goal in developing management strategies for the disease $(11,34)$. In the Pacific Northwest and intermountain region of North America, oospores are not currently known to be a factor in overwintering, and infected tubers are considered to be the main means of overwintering for the pathogen and the source of initial inoculum. Infected tubers serving as overwintering and primary inoculum sources may be potato seed tubers $(5,14,33)$, potato tubers left in the field after harvest that produce volunteer plants (34), and cull potato tubers $(4,15,34)$. The relative importance of the three types of infected tubers in temperate climates is unknown and may depend, in part, on microclimates, local conditions, and the extent of infection the previous fall $(5,34)$.

A continuum of viable host tissue is essential for survival and overwintering of $P$. infestans in potato-growing regions where oospores are not an overwintering factor (34). Contemporary isolates, particularly

Corresponding author: D. A. Johnson

E-mail: dajohn@wsu.edu

Accepted for publication 27 May 2009.

doi:10.1094/PDIS-93-9-0940

(C) 2009 The American Phytopathological Society the US-8 strain, are highly aggressive and rapidly rot tubers, limiting the availability of viable host tissue $(14,16)$. However, rotting by the US-8 strain of $P$. infestans did not occur over 7 weeks in inoculated tuber tissue at a storage temperature of $3^{\circ} \mathrm{C}$ (16). Recommended holding temperatures for tubers vary depending on end use. Seed potato tubers are stored between 3.3 and $4.4^{\circ} \mathrm{C}$, fresh market potato tubers are stored between 3.3 and $10^{\circ} \mathrm{C}$, while French fry and chip processing potato tubers are stored at 6.7 to $10^{\circ} \mathrm{C}$ and 10 to $12.7^{\circ} \mathrm{C}$, respectively (17). The optimal temperature for hyphal growth of $P$. infestans in potato tubers is about $10^{\circ} \mathrm{C}(14)$. However, the length of time infected tubers can remain intact in storage at temperatures used to store seed tubers is not known.

A large number of seed tubers are planted in potato production regions. For example, in the Columbia Basin of Washington and Oregon, approximately $8.7 \times$ $10^{8}$ seed tubers (assuming mean seed piece weight of $60 \mathrm{~g}$, mean seed tuber size of $170 \mathrm{~g}$, and $5 \%$ waste; 24,31 ) were cut and planted in 2007. P. infestans produces sporangia on infected tubers $(6,9,10,21,26)$ and the potential for multiple infections by $P$. infestans has been demonstrated when infected seed tubers are cut and handled (21). Because of the extremely large amount of seed tubers planted in a potato production region and the explosive polycyclic capabilities of $P$. infestans $(11,22,33)$, a greater understanding is needed of the survival of $P$. infestans in potato seed tubers.

Mycelium of $P$. infestans has been shown to persist in potato tubers by De
Bary and others $(7,22,33)$. Recently, latent infection of potato tubers by $P$. infestans has been implied in the Ecuadorian highlands (18). Latent infection was recently demonstrated when the pathogen was detected with the aid of polymerase chain reaction (PCR) in asymptomatic tubers $(1,2)$, sprouts, and stem $(2,3)$ in Germany and in asymptomatic tubers in Scotland (12). Infected seed tubers that survive in storage are a potential source of inoculum; therefore, the possibility of latent infection in stored seed tubers during extended storage periods needs to be investigated. The purpose of this research was to test the hypothesis that potato tubers can be latently infected with $P$. infestans during long-term cold storage and to determine the survivability of $P$. infestans in infected potato seed tubers of susceptible and moderately resistant cultivars at temperatures (near $4^{\circ} \mathrm{C}$ ) and time periods (6 to 7 months) used in commercial seed tuber production in the Pacific Northwest. Expression of late blight symptoms and production of sporangia were used to document the potential for continued disease development after latency. Inoculated and noninoculated tubers were also stored at a higher temperature $\left(8.4^{\circ} \mathrm{C}\right)$ as a comparison to the lower temperature.

\section{MATERIALS AND METHODS}

Four potato cultivars (Russet Burbank, Ranger Russet, Umatilla Russet, and Defender) were selected for this study. Russet Burbank, Ranger Russet, and Umatilla Russet are major potato cultivars grown in the Pacific Northwest of the United States. Defender is a recently released cultivar and is not commonly grown. Tubers of Russet Burbank and Ranger Russet are susceptible to $P$. infestans (28). Tubers of Umatilla Russet and Defender are considered moderately resistant and resistant, respectively, to $P$. infestans when compared with Ranger Russet (28).

Four US-8 isolates of the A2 mating type (Wa02, Web04, BF05, and Wa06) of $P$. infestans were selected for use in these studies because they represented the $P$. infestans population in the Pacific Northwest and were aggressive on potato tubers and foliage in preliminary tests. Isolates $\mathrm{Wa} 02$, Web04, and Wa06 were obtained from potato foliage collected from central Washington in 2002, 2004, and 2006, respectively. Isolate BF05 was obtained from potato foliage collected in northern Idaho 
in 2005. The isolates were maintained in potato tubers of Russet Burbank during winter months of October through March at $4.2^{\circ} \mathrm{C}$. Isolates were then maintained and increased on excised leaflets of Russet Burbank as described previously (30). Sporangia were washed from excised leaflets with distilled water. Concentration of sporangia was adjusted to 10,000 per milliliter of distilled water using a hemacytometer. Sporangia used for inoculation were chilled for $2 \mathrm{~h}$ at $4^{\circ} \mathrm{C}$ to induce zoospore formation. Inoculation was done by applying $0.05 \mathrm{ml}$ of inoculum with a micropipette to a Whatman no. 2 filter paper cut into 10-by-10-mm squares and then placing the saturated filter paper square onto a single eye on a tuber. Tubers used as noninoculated controls received a filter paper square saturated with distilled water and were subsequently treated the same as the inoculated tubers. All tubers used in these studies were produced in areas where late blight was not present and were assumed to be free of $P$. infestans.

Inoculated and noninoculated tubers were placed in a mist chamber and then allowed to dry. Tubers were then placed in one of three experimental cold-storage facilities for 30 to 209 days. Storage facility 1 was programmed at $8.4^{\circ} \mathrm{C}$ (mean $8.4^{\circ} \mathrm{C}$, range 7.7 to $9.4^{\circ} \mathrm{C}$ ) and was selected to represent storage temperature for French fry and chip processing potato tubers. Storage facilities 2 and 3 were programmed at $4.2^{\circ} \mathrm{C}$ (mean $4.2^{\circ} \mathrm{C}$, range 3.2 to $5.7^{\circ} \mathrm{C}$ ) and $4.1^{\circ} \mathrm{C}$ (mean $4.1^{\circ} \mathrm{C}$, range 3.2 to $4.9^{\circ} \mathrm{C}$ ), respectively, and were selected to represent temperatures used to store seed tubers. During the 2006-07 storage season, temperature and relative humidity were recorded every $15 \mathrm{~min}$ in storage facility 1 using model 450 Watch Dog Loggers (Spectrum Technologies, Inc., Plainfield, IL). Temperature was monitored in the remaining two storage facilities with thermometers. During the 2007-08 storage season, temperature and relative humidity were recorded in the three storage facilities using Watch Dog Loggers. Facilities 2 and 3 were selected with a mean difference of $0.1^{\circ} \mathrm{C}$ as a measure of replication and to ensure completion of the experiment if one storage facility malfunctioned.

Latent infection in stored tubers of Russet Burbank and Umatilla. Tubers of Russet Burbank and Umatilla Russet were inoculated in September 2006 with isolate BF05 to investigate latent infection during long-term cold storage. After inoculation, inoculated and noninoculated tubers were placed in a mist chamber for $20 \mathrm{~h}$ at 17 to $23^{\circ} \mathrm{C}$ and allowed to dry for $6 \mathrm{~h}$ at 20 to $23^{\circ} \mathrm{C}$. Tubers of each cultivar were then placed in the three storage facilities and arranged as a completely randomized design. Five inoculated and five noninoculated tubers of each cultivar were used for each sample time and each storage facility.
In facility 1 , tubers of each cultivar were destructively assessed for late blight severity at $34,48,71,91$, and 101 days, except that tubers of Umatilla Russet were not assessed at 91 days. In facilities 2 and 3, tubers of each cultivar were destructively assessed at 101, 125, 146, 167, 181 and 209 days. At each destructive sampling period, severity of late blight was visually assessed after cutting each tuber in a cross section at four places of approximately equal intervals. The surface areas formed from the cuts were rated individually for the percent area of internal rot. Tubers in facilities 2 and 3 that were asymptomatic for late blight based on external observation on the last assessment date at 209 days were not destructively sampled but, instead, were incubated at 22 to $23^{\circ} \mathrm{C}$ in the dark. Tubers were inspected every 2 to 3 days for late blight symptoms and signs over a 3-week period. Tubers were considered asymptomatic if no symptoms or signs were found following a thorough examination of the periderm for discoloration and eyes for necrosis. Small peels with a knife were made to observe internal tissue under the periderm and cuts were made into the eye where the inoculation was made to observe for discoloration and necrosis.

The experiment was repeated in September 2007 using methods as previously described, except as noted. The number of inoculated and noninoculated tubers for each cultivar and time period was four. Tubers stored in facility 1 were destructively assessed at 30, 60, and 91 days. Tubers stored in facilities 2 and 3 were destructively assessed for late blight at 30 , $60,91,122,150$, and 182 days of storage.

Tuber slices from 18 asymptomatic tubers collected from the six sampling periods were incubated in humidity chambers at $15^{\circ} \mathrm{C}$ to determine latency and incubation period until sporulation. Tuber slices were observed with a stereoscope at $\times 10$ to 62 magnifications for sporulation of $P$. infestans four times per week over 3 weeks. Time for sporangia to first be observed was recorded. Incubation period was the time period from initial incubation in the humidity chamber until sporangia were first observed. Each humidity chamber consisted of tuber slices $2 \mathrm{~cm}$ thick placed on a nylon screen over moistened filter paper in glass petri dishes $9.5 \mathrm{~cm}$ in diameter by $2.5 \mathrm{~cm}$ in height. Petri dishes were then placed in a 24-by-35-by-5-cm glass tray which was then sealed in a plastic bag.

Assays were conducted to determine incubation period until sporulation of symptomatic tubers. Cross sections from four tubers with severities of 20 to $70 \%$ of each Russet Burbank and Umatilla Russet from facilities 2 and 3 at the 150-day sampling period $(n=8)$ were placed in humidity chambers and incubated at $15^{\circ} \mathrm{C}$ for $48 \mathrm{~h}$ to promote sporangia formation. This was repeated with the same number of symptomatic tubers at the 182-day sampling period. The cut surface and eyes of the tuber disk were then observed for sporangia of $P$. infestans at 21,24 , and $48 \mathrm{~h}$ of incubation. Time for sporangia to first be observed was recorded.

Analyses of variance (ANOVAs) were done using PROC GLM in SAS (version 9.1; SAS Institute, Cary, NC). Incidence of tubers with late blight symptoms was the percentage of inoculated tubers with any late blight symptoms at the time of assessment. Severity of late blight was calculated from four cross-cut sections of tubers that had late blight symptoms. Data for incidence and severity of late blight for tubers collected from storage facilities 2 and 3 were analyzed separately from those collected from facility 1 due to noncontiguous assessment times and a large temperature difference. Trials in each storage facility were completely randomized factorial designs of two cultivars by assessment times measured as days after inoculation (DAI). The dependent variables were severity of late blight and incidence of tubers with symptoms. Tubers were treated as replications placed randomly by cultivar within a storage facility. For storage facility 1 , the number of assessment times was six and three for the two respective storage seasons, and data were analyzed as a two way factorial ANOVA with interaction. For storage facilities 2 and 3, the number of assessments was six for both storage seasons and data were analyzed as a threeway factorial where the two storages were treated as a fixed effect and the difference between the two storage facilities was not a factor of interest. Data from storage facilities 2 and 3 were combined each year because there were no significant $(P>$ 0.05 ) interactions for storages among cultivars or assessment times. Samples among assessment times were destructively assessed and, thus, were considered independent and not serially correlated. The $F$ test from the ANOVA was used to detect differences between cultivars for severity and incidence of late blight. The variance and normality assumptions for the ANOVAs were satisfied as determined by residual analysis. Standard errors between cultivars in Figures 1 through 4 were based on least-square means at each sample interval. Regression analysis was used to test for probability $(\operatorname{Pr}>F)$ of an increase of late blight severity and incidence over assessment times using PROC REG version 9.1 of SAS. Late blight severity and incidence were considered to increase if the regression coefficient (slope) was significantly greater than 0 at $P<0.05$. A log transformation of the dependent (severity) and independent (time) variables was done to satisfy normality and variance assumptions for disease severity data from storage facility 1 in 2006-07 and in storage facilities 2 and 3 in 2007-08. Student's $t$ test 
was used to test for a difference in length of incubation period until sporulation between symptomatic and asymptomatic tuber disks.

Latent infection in tubers caused by four isolates. Four isolates were used to more thoroughly sample the ability of the $P$. infestans population from the Columbia Basin to latently infect potato tubers than what one isolate would have provided. Tubers of Russet Burbank were inoculated at a single eye in October 2006 using the filter paper technique described previously with one of the four $P$. infestans isolates. Inoculated tubers were placed in a mist chamber for $24 \mathrm{~h}$ at 18 to $21^{\circ} \mathrm{C}$ and dried for $6 \mathrm{~h}$ at $21^{\circ} \mathrm{C}$. In all, 21 tubers were inoculated with Wa02, 24 with Web04, 17 with BF05, and 22 with Wa06.Tubers were arranged randomly and stored in facility 2 (mean $4.2^{\circ} \mathrm{C}$ ). Twenty tubers were used as controls. Symptomatic tubers were destructively assessed for late blight severity after 209 days of storage. Asymptomatic tubers were not cut but were held at 22 to $23^{\circ} \mathrm{C}$ in the dark for 3 weeks. Asymptomatic tubers in which late blight symptoms later developed were counted and then placed in a humidity chamber and incubated at $15^{\circ} \mathrm{C}$ for 48 $\mathrm{h}$ in the dark to promote sporangia formation.

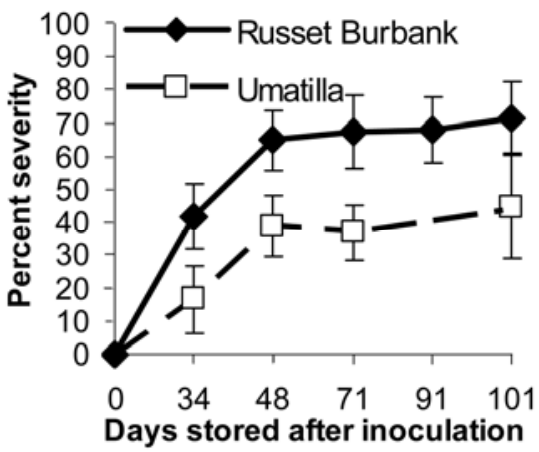

Fig. 1. Severity of late blight symptoms in tubers of cvs. Russet Burbank and Umatilla Russet stored at $8.4^{\circ} \mathrm{C}$ for 101 days during 2006-07. Standard error bars were based on least-square means at each sample interval.

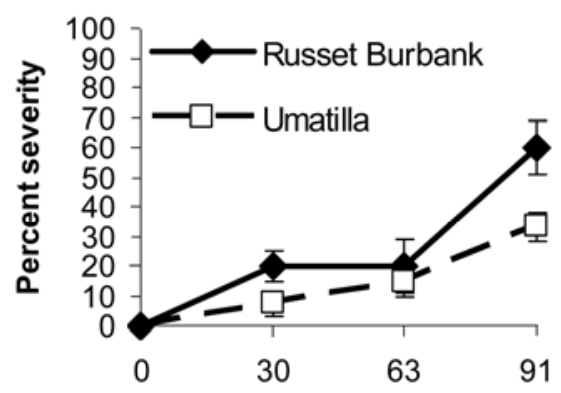

Days stored after inoculation

Fig. 2. Severity of late blight symptoms in tubers of cvs. Russet Burbank and Umatilla Russet stored at $8.4^{\circ} \mathrm{C}$ for 91 days during 2007-08. Standard error bars were based on least-square means at each sample interval.
The experiment was repeated with Umatilla Russet tubers in September 2007. Methods and experimental design were the same as in the first trial, except the number of tubers inoculated with each of the four isolates was 15 . The number of control tubers was 15. All tubers were destructively sampled after 182 days as described previously. Tuber slices from asymptomatic tubers were incubated in humidity chambers at $15^{\circ} \mathrm{C}$ and observed for sporulation of $P$. infestans four times per week over 3 weeks.

Data were analyzed as a completely randomized design one-way ANOVA. Trials (2006-07 and 2007-08) were not combined because different cultivars were used during the two storage seasons. Least significant difference $t$ tests for each trial was used for isolate comparison.

Effect of incubation time before cold storage on development of latent infection in tubers. Incubation time between inoculation and cold storage was varied to help determine whether a longer incubation would allow $P$. infestans to become more established in tuber tissue and, consequently, produce symptoms and reduce the frequency of latent infections of tubers. Tubers of Russet Burbank, Ranger Russet, Umatilla Russet, and Defender were inoculated in mid-September 2007 with isolate BF05 and placed in a mist chamber for 20 $\mathrm{h}$ at 16 to $19^{\circ} \mathrm{C}$. The number of tubers

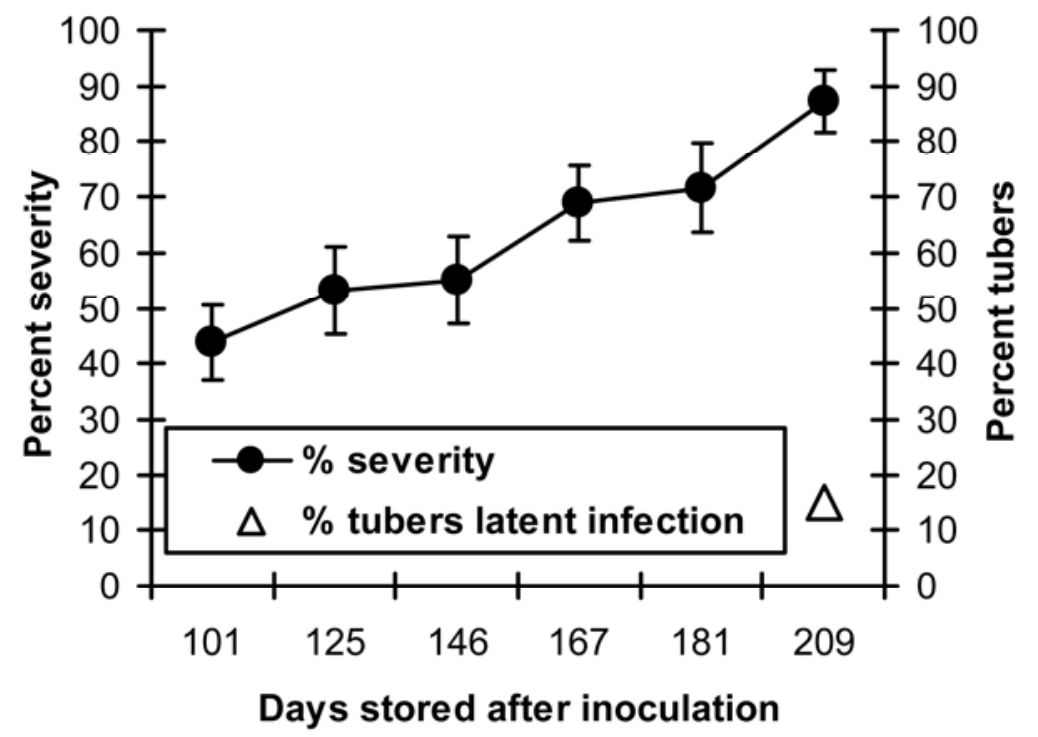

Fig. 3. Severity of late blight symptoms in tubers of cvs. Russet Burbank and Umatilla Russet and percent latent infection of tubers inoculated with Phytophthora infestans and stored at 4.2 and $4.1{ }^{\circ} \mathrm{C}$ for 101 to 209 days during the 2006-07 storage season. Standard error bars were based on least-square means at each sample interval.

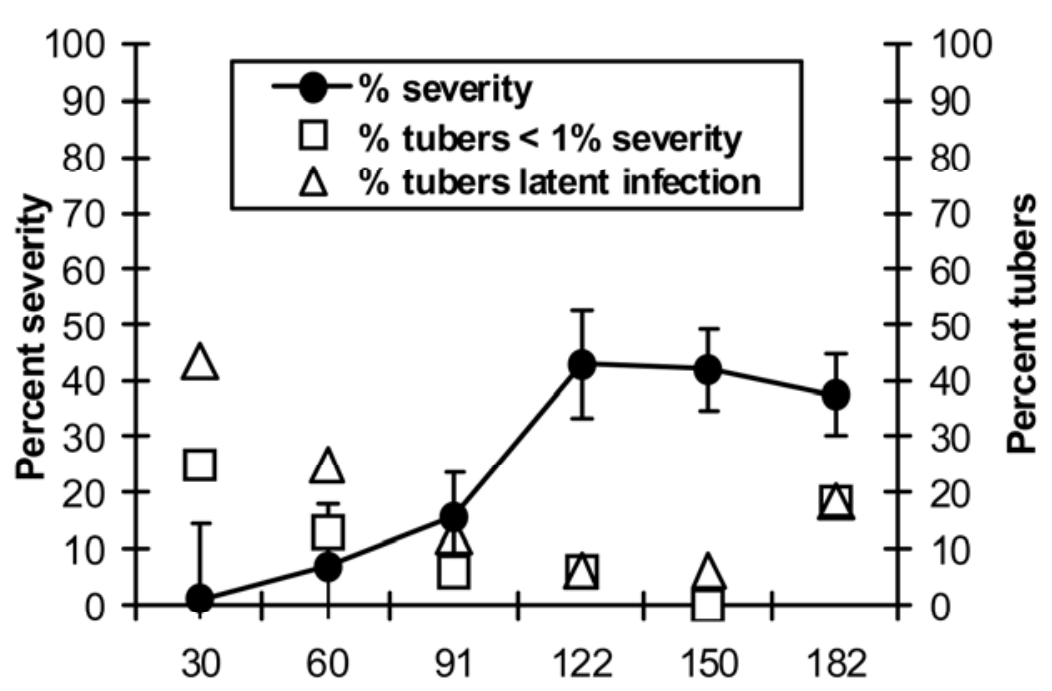

\section{Days stored after inoculation}

Fig. 4. Severity of late blight symptoms in tubers of cvs. Russet Burbank and Umatilla Russet, percentage of tubers with late blight symptom severity less than $1 \%$, and percent latent infection of tubers inoculated with Phytophthora infestans and stored at 4.2 and $4.1^{\circ} \mathrm{C}$ for 30 to 182 days during the 2007-08 storage season. Standard error bars were based on least-square means at each sample interval. 
inoculated per cultivar was 60. Twenty tubers of each cultivar were then incubated (dried) at $19^{\circ} \mathrm{C}$ for 1,6 , or $24 \mathrm{~h}$. Ten tubers for each drying time and cultivar were arranged in a completely randomized design and stored in facilities 2 and 3 . The number of control tubers for each drying time and temperature was 10 . Tubers were kept in storage for 182 days and symptomatic tubers were destructively sampled and assessed for late blight severity as described previously. Tubers that were asymptomatic for late blight based on external observation as described previously were not destructively sampled but instead were incubated at 22 to $23^{\circ} \mathrm{C}$. Tubers were then inspected every 2 to 3 days for late blight symptoms and signs over a 3-week period. The number of tubers developing late blight symptoms was recorded. Time of incubation until sporulation was determined for five tubers with severities between 1 and $10 \%$ as described previously. The experiment was repeated in October 2007.

Data for late blight incidence and severity were analyzed as a four-by-three factorial design of four cultivars by three incubation times (hours) randomly placed within two separate storages. Experimental units (cultivar by hours by storage) were replications of 10 tubers. When $F$ tests were significant, least significant difference was used to test for differences among cultivars and incubation times. Data from cultivar and incubation times from storage facilities 2 and 3 were combined because there were no significant $(P>0.05)$ differences between storages or interactions for storage-cultivar-incubation times.

\section{RESULTS}

Temperatures in facilities were uniform, as was made evident by relatively small standard errors (0.015 to 0.010$)$ and temperature ranges $\left(1.5^{\circ} \mathrm{C}\right)$ during both storage seasons. Temperatures as visually read from thermometers were also uniform for storage facilities 2 and 3 during the first storage season. Mean relative humidity was $89,70,99$ and $94 \%$ for storage facility 1 the first season, storage facility 1 the second season, storage facility 2 the second season, and storage facility 3 the second season, respectively. Relative humidity ranged from 77 to 97 and 61 to $80 \%$ for storage facility 1 during the first and second seasons, respectively. For storage facilities 2 and 3, relative humidity ranged from 92 to 100 and 81 to $99 \%$, respectively. Relative humidity was not recorded in storages facilities 2 and 3 during the first storage season but is expected to have been similar to that observed during the second storage season.

Latent infection in stored tubers of Russet Burbank and Umatilla. Severity of late blight in storage facility 1 was less for Umatilla Russet than for Russet Burbank during the first $(P=0.001)$ (Fig. 1) and second $(P=0.016)$ (Fig. 2$)$ storage seasons. Severity of late blight increased with time for Russet Burbank $(P=0.017)$ but not for Umatilla Russet $(P=0.073)$ during the first storage season (Fig. 1). Severity of late blight did not increase with time for Russet Burbank $(P=0.108)$ but did increase for Umatilla Russet $(P=$ 0.005) during the second storage season (Fig. 2). Incidence of tubers with late blight symptoms in storage facility 1 did not differ between Umatilla Russet and Russet Burbank the first storage season $(P$ $=0.056$ ) but incidence of late blight was greater for Umatilla Russet than for Russet Burbank in the second storage season $(P=$ 0.038). Mean incidence of late bight was $58 \%$ for the two cultivars in the first season and $42 \%$ for Russet Burbank and $83 \%$ for Umatilla Russet in the second storage season. Incidence of late blight symptoms did not increase with time for the first $(P=$ $0.122)$ and second $(P=0.545)$ storage seasons. Late blight did not develop in the noninoculated control tubers in storage facility 1 .

Severity of late blight in storage facilities 2 and 3 did not differ between the two cultivars during the first $(P=0.700)$ and second $(P=0.804)$ storage seasons or interact between storage facility and cultivar for both storage seasons $(P=0.567$ and 0.202 , respectively). As a result, disease severity data for storage facilities and cultivars were combined (Figs. 3 and 4). Severity of late blight increased for the combined cultivars in storage facilities 2 and 3 for both storage seasons $(P=0.001)$. Incidence of late blight in storage facilities 2 and 3 did not differ between cultivars during the first $(P=0.146)$ and second $(P$

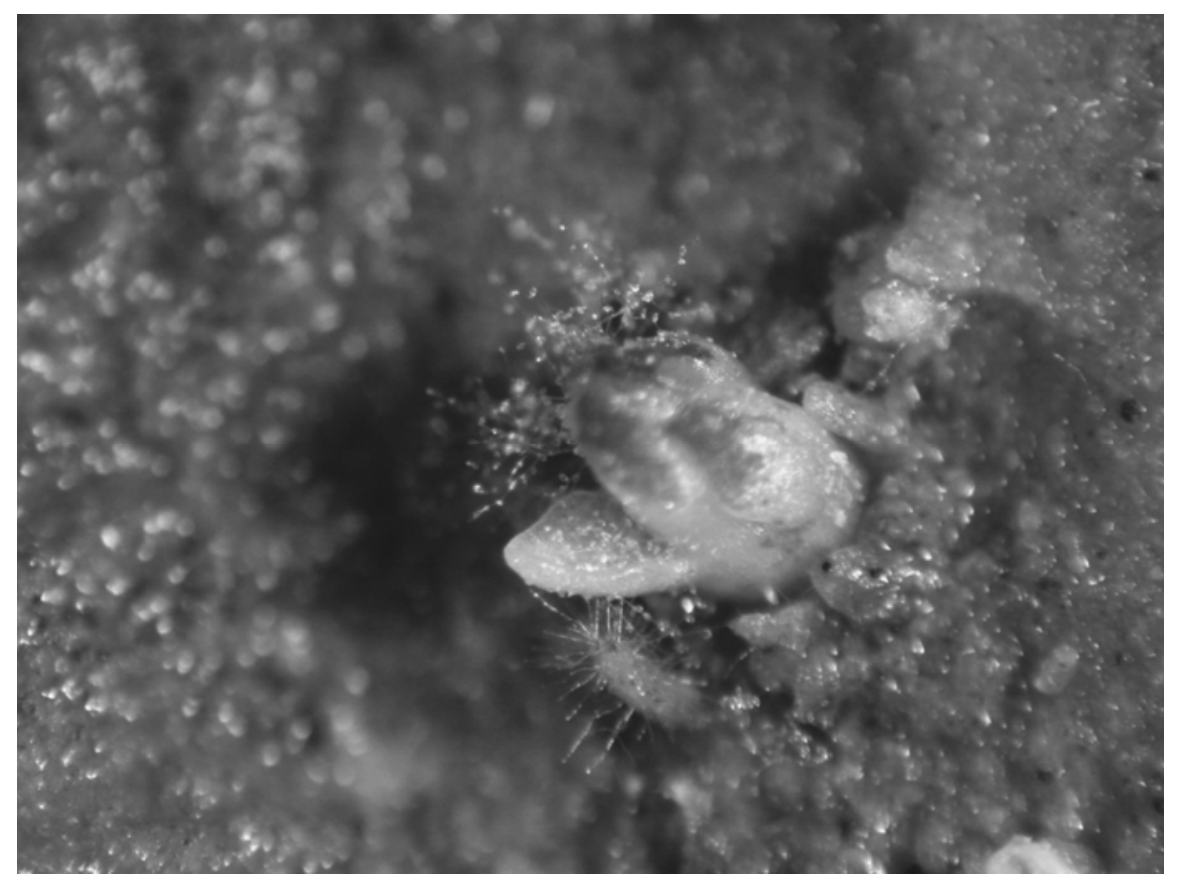

Fig. 5. Sporangia and sporangiophores of Phytophthora infestans on an emerging sprout from a potato tuber infected with $P$. infestans.

$=0.825)$ storage seasons. Mean incidence of late blight was $46 \%$ in the first season and $45 \%$ in the second season for the two cultivars. Incidence of late blight symptoms did not increase $(P=0.262)$ with time in storage facilities 2 and 3 during the first season. Incidence of late blight did increase $(P=0.014)$ in facilities 2 and 3 in the second storage season but the coefficient of determination was low, at 0.06 Late blight did not develop in the noninoculated control tubers in the three storage facilities 2 and 3 in both seasons.

For the first storage season in storage facilities 2 and 3, 10 and $20 \%$ of the inoculated Umatilla Russet and Russet Burbank tubers, respectively, were asymptomatic after 209 days of storage but later developed late blight symptoms when subsequently incubated at $23^{\circ} \mathrm{C}$ for 3 weeks. Thus, these tubers were latently infected (Fig. 3). Some eyes on tubers produced sprouts 1.5 to $6 \mathrm{~cm}$ in length before developing late blight lesions. Sporangia of $P$. infestans were produced on tuber eyes and slices when incubated in humidity chambers at $15^{\circ} \mathrm{C}$ (Fig. 5). For the second storage season in storage facilities 2 and 3, 0 to $25 \%$ of the inoculated tubers sampled monthly up to 182 days of storage had severities less than $1 \%$ (Fig. 4). In addition, 6 to $44 \%$ of the inoculated tubers were asymptomatic but tuber slices later supported production of $P$. infestans sporangia when incubated in a humidity chamber at $15^{\circ} \mathrm{C}$ (Fig. 4).

Incubation period until sporulation ranged from 6 to 20 days and had a mean of 9.6 days when tuber slices from asymptomatic tubers were incubated in a humidity chamber at $15^{\circ} \mathrm{C}$. Sporangia were ob- 
served on the cut surface and eyes of 14 tuber slices from symptomatic tubers at 24 $\mathrm{h}$ and 2 tuber disks at $21 \mathrm{~h}$. The difference lation between asymptomatic and symptomatic tubers disks was significant at $P<$ 0.0001 . Sporulation was light at $21 \mathrm{~h}$, with less than 20 sporangiophores with sporangia on an eye or cut surface. The amount of sporulation increased with time of incubation.

Soft rot and dry rot symptoms occurred in some late-blight-symptomatic tubers sampled during the latter assessment times in both storage seasons. During the first storage season at 181 and 209 days, mean incidence and severity of bacterial soft rot symptoms were each $10 \%$. Fusarium dry storage season at 150 and 182 days, mean incidence and severity of Fusarium dry rot in length of incubation period until sporurot was not evident. During the second

symptoms were 13 and $15 \%$, respectively. Bacterial soft rot did not exceed $1 \%$ severity in the second storage season.

Latent infection in tubers caused by four isolates. Incidence of tubers with late blight symptoms ranged from 32 to $100 \%$ for Russet Burbank tubers inoculated with one of four isolates of $P$. infestans and stored in storage facility 2 for 209 days during the first storage season. Mean severity of late blight symptoms for tubers with symptoms ranged form 68 to $89 \%$. Severity of late blight was significantly $(P$ $<0.05)$ greater in tubers inoculated with isolate Web04 than with isolates BF05 and Wa06 (Table 1).

Late blight symptoms developed in inoculated tubers that were asymptomatic after 209 days of storage when they were subsequently incubated at $23^{\circ} \mathrm{C}$ for 3 weeks. Percent latent tuber infection

Table 1. Incidence and severity of late blight symptoms and percent latent infection of tubers of cv. Russet Burbank inoculated with one of four isolates of Phytophthora infestans and stored in facility 2 $\left(4.2^{\circ} \mathrm{C}\right)$ for 209 days during $2006-07^{\mathrm{z}}$

\begin{tabular}{lcccc}
\hline Isolate & $\begin{array}{c}\text { Total } \\
\text { tubers }(\boldsymbol{n})\end{array}$ & $\begin{array}{c}\text { Incidence of tubers } \\
\text { with symptoms (\%) }\end{array}$ & $\begin{array}{c}\text { Severity of tubers } \\
\text { with symptoms (\%) }\end{array}$ & $\begin{array}{c}\text { Latent tuber } \\
\text { infection (\%) }\end{array}$ \\
\hline Wa02 & 21 & 62 & $81 \mathrm{ab}$ & 33 \\
Web04 & 24 & 75 & $89 \mathrm{a}$ & 4 \\
BF05 & 17 & 100 & $68 \mathrm{~b}$ & 0 \\
Wa06 & 22 & 32 & $69 \mathrm{~b}$ & 9 \\
\hline
\end{tabular}

${ }^{\mathrm{z}}$ Values within a column with the same letter are not significantly different at $P=0.05$, according to Fisher's protected least significant difference. No significant differences in columns without letters.

Table 2. Incidence and severity of late blight symptoms, percentage of tubers with late blight symptom severity less than $1 \%$, and percent latent infection of tubers of Umatilla Russet inoculated with one of four isolates of Phytophthora infestans and stored facility $2\left(4.2^{\circ} \mathrm{C}\right)$ for 182 days during 2007-08

\begin{tabular}{lcccc}
\hline Isolate & $\begin{array}{c}\text { Incidence of tubers } \\
\text { with symptoms } \\
(\boldsymbol{\%})\end{array}$ & $\begin{array}{c}\text { Severity of tubers } \\
\text { with symptoms } \\
(\mathbf{\%})\end{array}$ & $\begin{array}{c}\text { Tubers with } \\
\text { symptom severity } \\
<\mathbf{1 \%}(\boldsymbol{\%})\end{array}$ & $\begin{array}{c}\text { Latent tuber } \\
\text { infection } \\
(\boldsymbol{\%})\end{array}$ \\
\hline Wa02 & 60 & $47 \mathrm{~b}$ & 20 & 20 \\
Web04 & 100 & $72 \mathrm{a}$ & 7 & 0 \\
BF05 & 93 & $77 \mathrm{a}$ & 7 & 0 \\
Wa06 & 87 & $65 \mathrm{ab}$ & 13 & 0 \\
\hline
\end{tabular}

${ }^{\mathrm{z}}$ Total inoculated tubers per isolate $(n)$ was 15 . Values within a column with the same letter are not significantly different at $P=0.05$, according to Fisher's protected least significant difference. No significant differences in columns without letters.

Table 3. Incidence and severity of late blight symptoms, percentage of tubers with late blight symptom severity less than $1 \%$, and percent latent infection of tubers of four potato cultivars inoculated with an isolate of Phytophthora infestans and stored in facilities 2 and $3\left(4.1\right.$ and $\left.4.2^{\circ} \mathrm{C}\right)$ for 182 days in two trials during $2007-08^{\mathrm{z}}$

\begin{tabular}{lcccc}
\hline Trial, cultivar & $\begin{array}{c}\text { Incidence of } \\
\text { tubers with } \\
\text { symptoms (\%) }\end{array}$ & $\begin{array}{c}\text { Severity of } \\
\text { tubers with } \\
\text { symptoms (\%) }\end{array}$ & $\begin{array}{c}\text { Tubers with } \\
\text { symptom severity } \\
\mathbf{< 1 \%}(\mathbf{\%})\end{array}$ & $\begin{array}{c}\text { Latent tuber } \\
\text { infection } \\
(\%)\end{array}$ \\
\hline First trial & & & & \\
Ranger Russet & $60 \mathrm{a}$ & $85 \mathrm{a}$ & 5.0 & 5.0 \\
Russet Burbank & $33 \mathrm{~b}$ & $50 \mathrm{ab}$ & 0 & 1.7 \\
Umatilla Russet & $3 \mathrm{c}$ & $21 \mathrm{~b}$ & 1.7 & 0 \\
Defender & $2 \mathrm{c}$ & $20 \mathrm{~b}$ & 0 & 1.7 \\
Second trial & $71 \mathrm{a}$ & $85 \mathrm{a}$ & 3.3 & 0 \\
Ranger Russet & $49 \mathrm{~b}$ & $41 \mathrm{~b}$ & 0 & 0 \\
Russet Burbank & $0 \mathrm{c}$ & $\ldots$ & 0 & 0 \\
Umatilla Russet & $7 \mathrm{c}$ & $11 \mathrm{c}$ & 0 & 0 \\
Defender & &
\end{tabular}

${ }^{\mathrm{z}}$ Total number of tubers per cultivar $(n)$ at each storage facility was 30 . Values within a column with the same letter are not significantly different at $P=0.05$, according to Fisher's protected least significant difference. Data were combined for storage facilities and prestorage incubation periods. No significant differences in columns without letters. ranged from 0 to $33 \%$ of the inoculated tubers for the four isolates (Table 1). Sprouts from tuber eyes grew 1.5 to $4 \mathrm{~cm}$ in length before developing late blight symptoms when latently infected tubers were incubated at $23^{\circ} \mathrm{C}$. Sporangia of $P$. infestans were produced on tubers slices, tubers, and sprouting eye upon incubation in humidity chambers at $15^{\circ} \mathrm{C}$. Late blight symptoms did not develop in the noninoculated control tubers. Some tubers with late blight symptoms also had soft rot and dry rot symptoms. Mean incidence and severity of bacterial soft rot symptoms was 33 and $10 \%$, respectively. Mean incidence and severity of Fusarium dry rot symptoms was 18 and 5\%, respectively.

During the second storage season, incidence of tubers with late blight symptoms ranged from 60 to $100 \%$ for Umatilla Russet tubers inoculated with one of four isolates of $P$. infestans and stored at $4.2^{\circ} \mathrm{C}$ for 182 days. Mean severity of late blight symptoms for tubers with symptoms ranged from 47 to $77 \%$. Severity of late blight symptoms was significantly greater in tubers inoculated with isolates Web04 and BF05 than with isolate $\mathrm{Wa02}$ (Table 2).

In all, $20 \%$ of the tubers inoculated with isolate $\mathrm{Wa02}$ did not exhibit late blight symptoms after 182 days of storage in facility 2. However, sporangia of $P$. infestans developed on tuber slices from these tubers when incubated in humidity chambers at $15^{\circ} \mathrm{C}$ (Table 2). The incubation period until sporulation ranged from 7 to 15 days with a mean of $10(n=3)$ when tuber slices from asymptomatic tubers were incubated in humidity chamber at $15^{\circ} \mathrm{C}$. Late blight symptoms did not develop in the noninoculated control tubers. Bacterial soft rot was not evident in tubers. Some tubers with late blight symptoms also had Fusarium dry rot symptoms. Mean incidence and severity of Fusarium dry symptoms were both $5 \%$.

Effect of incubation time before cold storage on development of latent infection in tubers. Late blight severity data from storage facilities 2 and 3 were combined because $F$ tests were not significant between storages for the first $(P=0.131)$ and second storage seasons $(P=0.609)$. Late blight incidence $(P=0.705$ and 0.075 for the two trials, respectively) and severity $(P=0.493$ and 0.269 for the two trials, respectively) were not significantly different among the 1-, 6-, and 24-h incubation periods between the end of the mist period and placement of tubers in cold storage and, thus, data were combined. Disease severity of tubers with symptoms was significantly $(P<0.05)$ greater for Ranger Russet than for the other three cultivars, except for Russet Burbank in the first trial (Table 3). Incidence of infection was significantly $(P<0.05)$ greater for Umatilla Russet and Defender than for Ranger Russet and Russet Burbank in both trials (Table 3). 
Up to $5 \%$ of the inoculated tubers had late blight severities less than $1 \%$ after 182 days of storage (Table 3). Fifteen tubers $(6.3 \%)$ had severities of 5 to $10 \%$ in the two trials (data not shown). In all, $5 \%$ of the Ranger Russet and $1.7 \%$ of both the Umatilla Russet and Defender tubers in the first trial were asymptomatic after 182 days of storage but later developed late blight symptoms when incubated at 22 to $23^{\circ} \mathrm{C}$ for 13 days. Frequency of latent infection was not found to be associated with length of incubation time used in this study before cold storage. In the first trial, numbers of latently infected tubers of the four cultivars combined was 0,4 , and 1 at 1,6 , and $24 \mathrm{~h}$ of incubation, respectively. Latently infected tubers were not detected in the second trial.

Incubation period until sporulation on tubers with late blight severities of 1 to $10 \%$ ranged from 3 to 8 days $($ mean $=4.6$ days) when tubers that eventually developed late blight symptoms were incubated in a humidity chamber at $15^{\circ} \mathrm{C}$. Late blight symptoms did not develop in the noninoculated control tubers. For both trials, incidence and severity of bacterial soft rot symptoms were 2 and $30 \%$, respectively. Incidence and severity of Fusarium dry rot symptoms were 8 and 50\%, respectively.

\section{DISCUSSION}

$P$. infestans is known to persist in potato tubers during storage (5) but survivability in seed tubers under extended storage conditions at typical seed storage temperatures has not been known until this study. Isolates of the US 8 and other new clonal lineages of $P$. infestans are aggressive in potato tubers and quickly rot infected tubers at temperatures above $10^{\circ} \mathrm{C}$ $(13,20,25)$. Mycelium of $P$. infestans is no longer able to survive in tubers once the host tissue is completely rotten $(11,21)$. Tubers of Russet Burbank and Umatilla Russet infected with US 8 isolates in this study were mostly rotten within 3 months at $8.4^{\circ} \mathrm{C}$ (Fig. 1). However, a substantial proportion of the infected tubers stored near $4^{\circ} \mathrm{C}$ did not completely rot and isolates of the US8 clonal lineage persisted in potato seed tubers during an extended storage season of 6 to 7 months at temperatures used to store seed tubers.

Variation for severity of late blight symptoms in infected tubers in long-term cold storage was high in this study. Tubers with late blight severities of less than $1 \%$ were common. All tubers with low severities of symptoms are not likely to be detected and disposed of during handling, inspection, cutting, and planting. Such tubers are capable of supporting sporangia and perpetuating the pathogen as they continue through the process of handling to planting.

A latent infection of tubers was demonstrated in that some tubers were asymptomatic and did not exhibit late blight symp- toms of discoloration or necrosis on the external or in the internal tissues at the end of a storage period. However, symptoms and sporangia of $P$. infestans developed on asymptomatic tubers when they were placed at temperatures of $15^{\circ} \mathrm{C}$ and above. The percentage of latently infected tubers ranged from 0 to $44 \%$ in this study. Eyes of tubers with low severities of late blight and of tubers with latent infections were viable and sprouted after storage. Sporangia developed on sprouts from asymptomatic tubers after storage when later incubated at high humidity and $15^{\circ} \mathrm{C}$. This suggests that a relatively high number of tubers may be latently infected when taken out of environments typical of commercial seed tuber storage.

Each of the four isolates tested in this study produced latent infection in longterm cold storage. The amount of latently infected tubers likely depends, in part, on the level and extent of infection the preceding fall. Various factors influence infection of tubers near harvest $(13,19,23,26$, $27,29,30)$. Latent infection of asymptomatic tubers also has been demonstrated with the aid of PCR $(1,2,12)$. However, PCR detection does not demonstrate that viable tissue of $P$. infestans is in the tuber and capable of eventually producing inoculum. In the current study, late blight symptoms development and viable inoculum were demonstrated after an extensive storage period of latency. Latently infected seed tubers are likely another important inoculum source of $P$. infestans.

A potential for secondary cycles of infection by $P$. infestans during seed-tuber cutting and handling has been documented (21). Sporulation of $P$. infestans occurred within $21 \mathrm{~h}$ at high humidity after seed tubers with late blight symptoms were removed from cold storage to a warmer environment in this study. Sporangia were readily transmitted by direct contact from tubers or seed pieces to noninfected seed pieces in a previous study (9). Sporangia can potentially become airborne and carried by air currents to cut tuber surfaces or tuber eyes within a storage and cutting facility or to plants and soil in the field, resulting in additional infections (18). Potato handling and cutting facilities are generally enclosed, blocking incoming solar radiation, which would also increase longevity of sporangia (32).

The extended incubation period until sporulation of 6 to 20 days for latently infected tubers, 3 to 8 days for tubers with 1 to $10 \%$ disease severity, and 1 to 2 days for tubers with 20 to $70 \%$ disease severities indicated varied degrees of establishment $P$. infestans in tuber tissue. Sporulation of $P$. infestans over an extended time period on tubers taken from storage could be expected because of varying degrees of infection. This would provide an extended time period for sporangia to be produced and present during handling and cutting of seed tubers and increase the probability for secondary infections between storage and planting.

Severity of late blight was significantly less for Umatilla Russet than for Russet Burbank at $8.4^{\circ} \mathrm{C}$ (storage facility 1) up to 100 days of storage but not at 4.2 and $4.1^{\circ} \mathrm{C}$ (storage facilities 2 and 3 ) for 182 to 209 days of storage. Results of the longer storage periods at 4.1 to $4.2^{\circ} \mathrm{C}$ differed from a previous study where Umatilla Russet was more resistant than Russet Burbank based on tuber severity. However, in the previous study (28), inoculated tubers were stored for only 36 days at $9^{\circ} \mathrm{C}$. Long storage periods at temperatures near $4^{\circ} \mathrm{C}$ may have negated the effects of the moderate resistance based on disease severity in Umatilla Russet in this study. Tubers of Defender and Umatilla Russet were more resistant than those of Ranger Russet for 182 days in storage near $4^{\circ} \mathrm{C}$ based on incidence and severity of infection in this study and based on severity of infection at $9^{\circ} \mathrm{C}$ in a previous study (28).

Pectolytic bacteria often infect potato tubers after initial infection with $P$. infestans. Latently infected tubers that were detected were not affected by bacterial soft rot or Fusarium dry rot in this study. $P$. infestans is a poor competitor against soft rotting bacteria (14). Secondary infection would eliminate long-term survival of $P$. infestans in stored tubers $(10,14)$. Wounding of tubers facilitates infection by pectolytic bacteria (8), and soft rot was not a major issue in this study likely because tubers were not wounded before inoculating with $P$. infestans. Wounding tubers to inoculate with $P$. infestans may also alter resistance reaction to $P$. infestans $(6,25)$. Also, tuber surfaces were dry before placing in cold storage, eliminating possible anaerobic conditions created by a water film on tuber surfaces that favor pectolytic bacteria (8). Storage temperatures below $5^{\circ} \mathrm{C}$ also inhibit development of bacterial soft rot in potato tubers (8).

In summary, $P$. infestans is capable of surviving asymptomatically and at low severities of symptoms development in potato seed tubers for extended time periods at temperatures around $4{ }^{\circ} \mathrm{C}$. Latent infection of seed tubers poses a challenge for management of late blight. Visual inspection of tubers will not reveal latently infected tubers and tubers with low severities of infection may be overlooked (18). Molecular techniques are available to detect latent tuber infections $(1,2,3,12)$. Such techniques and tuber sampling procedures need to be developed and utilized to accurately detect latent tuber infections and low incidences of infection in potato seed lots.

\section{ACKNOWLEDGMENTS}

Partial funding for this study was provided by the Washington State Potato Commission. PPNS no. 0501, Department of Plant Pathology, College of Agricultural, Human, and Natural Resource Sciences Agricultural Research Center, Project no. 
WNPO 0678, Washington State University, Pullman, WA 99164-6430. We thank D. Inglis and L. Porter for a critical presubmission review of the manuscript.

\section{LITERATURE CITED}

1. Adler, N., Appel, R., and Habermeyer, J. 2001. Field experiments with seed treatment against late blight. PAV Rep. No. 7, February 2001. Appl. Res. Arable Farm. Field Prod. Veg. 7:153-163.

2. Adler, N., Habermeyer, J., and Zinkernagel, V. 1999. PCR techniques used for detection of Phytophthora infestans latent infections in potato. PAV. Rep. No. 5, January 1999. Appl. Res. Arable Farm. Field Prod. Veg. 5:247-255.

3. Appel, R., Adler, N., and Habermeyer, J. 2001. A method for the artificial inoculation of potato tubers with Phytophthora infestans and polymerase chain reaction assay of latently infected sprouts and stems. J. Phytopathol. 149:287-292.

4. Boyd, A. E. W. 1974. Sources of potato late blight (Phytophthora infestans) in the east of Scotland. Plant Pathol. 23:30-36.

5. Davidse, L. C., Henken, J., van Dalen, A., Jespers, A. B. K., and Mantel, B. C. 1989. Nine years of practical experience with phenylamide resistance in Phytophthora infestans in the Netherlands. Neth. J. Plant Pathol. 95(Suppl. 1):197-213.

6. Davila, E. 1964. Late blight infection of potato tubers. Am. Potato J. 4:103-112.

7. De Bary, A. 1876. Researches into the nature of the potato-fungus-Phytophthora infestans. J. R. Agric. Soc 12:239-269.

8. De Boer, S. H. 2008. Managing soft rot and ring rot. In: Potato Health Management, Second ed. D. A. Johnson, ed. American Phytopathological Society Press, St. Paul, MN.

9. Dowley, L. J., and O'Sullivan, E. 1991. Sporulation of Phytophthora infestans (Mont.) De Bary on the surface of diseased potatoes and tuber to tuber spread of infection during handling. Potato Res. 34:295-296.

10. Gigot, J. A., Gundersen, B., and Inglis, D. A. Colonization and sporulation of Phytophthora infestans on volunteer potatoes under northwestern Washington conditions. Am. J. Potato Res. In press.

11. Hirst, J. M., and Stedman, O. J. 1960. The epidemiology of Phytophthora infestans II. The source of inoculum. Ann. Appl. Biol.
48:489-517.

12. Hussain, S., Lees, A. K., Duncan, J. M., and Cooke, D. E. L. 2007. Development of a species-specific and sensitive detection assay for Phytophthora infestans and its application for monitoring of inoculum in tubers and soil. Plant Pathol. 54:373-382.

13. Johnson, D. A., Martin, M., and Cummings, T. F. 2003. Effect of chemical defoliation, irrigation water, and distance from the pivot on late blight tuber rot in center-pivot irrigated potatoes in the Columbia Basin. Plant Dis. 8:977982.

14. Kadish, D., and Cohen, Y. 1992. Overseasoning of metalaxyl-sensitive and metalaxylresistant isolates of Phytophthora infestans in potato tubers. Phytopathology 82:887-889.

15. Kirk, W. W. 2003. Thermal properties of overwintered piles of cull potatoes. Am. J. Potato Res. 80:145-149.

16. Kirk, W. W., Niemira, B. A., and Stein, J. M. 2001. Influence of storage temperature on rate of potato tuber tissue infection caused by $P h y$ tophthora infestans (Mont.) de Bary estimated by digital image analysis. Potato Res. 44:8696.

17. Knowles, N. R., and Plissey, E. S. 2008. Maintaining tuber health during harvest, storage, and post-storage handling. In: Potato Health Management, Second ed. D. A. Johnson, ed. American Phytopathological Society Press, St. Paul, MN.

18. Kromann, P., Taipe, A., Andrade-Piedra, J. L., Munk, L., and Forbes, G. A. 2008. Preemergence infection of potato sprouts by Phytophthora infestans in the highland tropics of Ecuador. Plant Dis. 92:569-574.

19. Lacey, J. 1965. The infectivity of soils containing Phytophthora infestans. Ann. Appl. Biol. 56:363-380.

20. Lambert, D. H., and Currier, A. I. 1997. Differences in tuber rot development for North American clones of Phytophthora infestans. Am. Potato J. 74:39-43.

21. Lambert, D. H., Currier, A. I., and Olanya, M. O. 1998. Transmission of Phytophthora infestans in cut potato seed. Am. J. Potato Res. 75:257-263.

22. Melhus, I. E. 1915. Hibernation of Phytophthora infestans in the Irish potato. J. Agric. Res. 5:71-112.

23. Miller J. S., Cummings, R. F., Mikitzel, L. J., and Johnson, D. A. 2002. Influence of timing of harvest in relation to haulm killing and planting date on potato tuber rot caused by Phytophthora infestans. Plant Dis. 86:264-268.

24. Pavek, M. J., and Thornton, R. E. 2005. A survey of stand establishment and in-row spacing uniformity in Washington potato fields. Am. J. Potato Res 82:463-469.

25. Peters, R. D., Platt, H. W., Hall, R., and Medina, M. 1999. Variation in aggressiveness of Canadian isolates of Phytophthora infestans as indicated by their relative abilities to cause potato tuber rot. Plant Dis. 83:652-661.

26. Platt, H. W., Peters, R. D., Medina, M., and Arsenault, W. 1999. Impact of seed potatoes infected with Phytophthora infestans (US-1 or US-8 genotypes) on crop growth and disease risk. Am. J. Potato Res. 75:67-73.

27. Porter, L. D., Dasgupta, N., and Johnson, D. A. 2005. Effects of tuber depth and soil moisture on infection of potato tubers in soil by Phytophthora infestans. Plant Dis. 89:146-152.

28. Porter, L. D., Inglis, D. A., and Johnson, D. A. 2004. Identification and characterization of resistance to Phytophthora infestans in leaves, stems, flowers, and tubers of potato clones in the Pacific Northwest. Plant Dis. 88:965-972.

29. Porter, L. D., and Johnson, D. A. 2006. Effects of soil-applied late blight foliar fungicides on infection of potato tubers by Phytophthora infestans. Plant Dis. 90:964-968.

30. Porter, L. D., and Johnson, D. A. 2007. Survival of sporangia of new clonal lineages of Phytophthora infestans in soil under semiarid conditions. Plant Dis. 91:835-841.

31. Secor, G. A., and Johnson, S. B. 2008. Seed tuber health before and during planting. In: Potato Health Management, Second ed. D. A. Johnson, ed. American Phytopathological Society Press, Press. St. Paul, MN.

32. Sunseri, M. A., Johnson, D. A., and Dasgupta, N. 2002. Survival of detached sporangia of Phytophthora infestans exposed to ambient, relatively dry atmospheric conditions. Am. J. Potato Res. 79:443-450.

33. Van der Zaag, D. E. 1956. Overwintering en epidemiologie van Phytophtora infestans, tevens einige nieuwe bestrijdingsmoelijkheden. Tijdschr. Plantenziekten 62:89-156.

34. Zwankhuizen, M. J., Govers, F., and Zakoks, J. C. 1998. Development of potato late blight epidemics: disease foci, disease gradients, and infection sources. Phytopathology 88:754-763. 